\title{
Social Media: A New Frontier for Retailers?
}

\author{
Efthymios Constantinides, Carlota Lorenzo Romero and Miguel A. Gómez Boria
}

\begin{abstract}
During the last two decades the retailing industry is finding itself in a state of constant evolution and transformation. Globalization, mergers and acquisitions, and technological developments have drastically changed the retailing landscape. The explosive growth of the Internet has been one of the main catalysts in this process. The effects of the Internet have been mostly felt in retail sectors dealing mainly with intangibles or information products. But these are not likely to be limited to these sectors; increasingly retailers of physical products realize that the empowered, sophisticated, critical and well-informed consumer of today is essentially different to the consumer they have always known. The web, and particularly what is known as Social Media or Web 2.0, have given consumers much more control, information and power over the market process, posing retailers with a number of important dilemmas and challenges. This article explains what the new face of the Internet, widely referred to as Web 2.0 or Social Media, is, identifies its importance as a strategic marketing tool and proposes a number of alternative strategies for retailers. Implementing such strategies will allow retailers not only to survive, but also create competitive advantages and thrive in the new environment.
\end{abstract}

\section{Keywords}

Social Media, Web 2.0, Retailing, Internet Retailing, Customer Behaviour, Online Strategy

Efthymios Constantinides (corresponding author)

Faculty of Management and Governance, University of Twente, Enschede, The Netherlands

(Tel: ++31 53489 3799; E-mail: e.constantinides@utwente.nl).

Carlota Lorenzo Romero

Faculty of Economics and Business, Department of Marketing, University of Castilla-La Mancha, Spain.

Miguel A. Gómez Boria

Faculty of Economics and Business, Department of Marketing, University of Castilla-La Mancha, Spain.

Received: March 10, 2008

Revised: June 15, 2008

Accepted: June 23, 2008
EUROPEAN 


\section{Introduction}

Fifteen years after its commercial launching, the Internet has become the second most important distribution channel (after high street retailing) and a major source of customer information and empowerment (Urban 2003, 2005; Constantinides/Fountain 2008). A number of recent developments in this field threaten to further weaken the role of traditional retailing in a number of sectors where retailers and intermediaries have always played an important role. Music, entertainment, press, printing/publishing and traditional travel agents are some of the branches that have already felt the negative effects of Internet-enabled disintermediation. The web has made possible the direct contact between producers and consumers, making the physical retailer of information-based products or intangibles redundant.

These developments are widely seen as effects of the Internet evolution and have been extensively discussed and debated. However, over the last three years, a new generation of online tools, applications and approaches such as blogs, wikis, online communities and virtual worlds, commonly referred to as Web 2.0 or Social Media, are increasingly attracting the attention of practitioners and, recently, of academics. As often happens when revolutionary innovations become booming business, research and theoretical underpinning on the Web 2.0 issue is still very limited and there is not even a generally accepted definition. What most people would agree though is that a fundamental element of Web 2.0 is what is widely known as Customer-Generated Content (CGC): besides extracting value, users also add value to Web 2.0 applications and processes by generating, reviewing, editing and disseminating content. Direct customer involvement and CGC result in powerful network effects and users' communities (O’Reilly 2005).

This article identifies the theoretical foundations of the Web 2.0 movement, based on the definition of the term proposed by Constantinides/Fountain (2008), and describes the main dimensions and elements of Web 2.0 applications. It examines the effects of Social Media on the consumer decision-making process and proposes a number of ways that corporations and retailers, in particular, can implement such applications as part of their marketing plan.

\section{The Internet / Web 2.0 as Commercial Platform}

While the Web 2.0 issue enjoys a lot of publicity and many businesses are rushing to integrate various forms of Social Media applications into their marketing strategies, very limited academic attention has been paid so far to strategic and commercial aspects of this phenomenon and, specifically, its appropriateness and importance as a strategic marketing tool. Most of the recently published articles are focused on describing the technical, social and commercial effects of Web 2.0 applications rather than analyzing the strategic nature of the phenomenon and the applications themselves. The vast majority of businesses and consumers in several 
parts of the world have already adopted the Internet as a mainstream information medium, and often as a transaction and distribution channel. For an increasing segment of the approximately 1.5 bn online users, the web is already the main - if not the only - source of information (Zogby International 2008) and a popular channel for commercial transactions: Eightyfive per cent of the online consumers shopped online in 2007 according to Nielsen Online. According to a recent Newsweek (2007) article "the web has replaced phone books, and is in the process of replacing phones. It's the place that answers our questions in four tenths of a second $[. .$.$] it's the main news source [. .$.$] a megaphone for those who make their own media$ $[\ldots]$ ". For businesses, the Internet is widely seen as a major commercial platform and indispensable part of their strategic planning (McKinsey 2007c).

Some recently published studies underline the growing importance of the Internet as interactive communication environment and social interaction platform (McAfee 2006; Birdsall 2007; Beer/Burrows 2007). These areas represent some exciting developments in the web domain, namely the fast growth of a new breed of online applications and technologies often referred to as Web 2.0 [1]. These applications and technologies are shaping business processes (Swisher 2007; Craig 2007), consumer behaviour (Deighton/Kornfeld 2007) and marketing practices (Hoegg et al. 2006; Parise/Guinan 2008; Constantinides/Fountain 2008; Bernhoff/Li 2008). In less than three years after the term Web 2.0 was introduced, an increasing number of corporations are rushing to integrate various forms of it into their marketing strategies. Studies published by McKinsey (2007 a, b) and Li et al. (2007) indicate the rising popularity of Web 2.0 among businesses and the increasing willingness of companies to expand their activities in this domain. A study conducted by prospero.com (2007) estimates that $88 \%$ of businesses expect to increase their spending on Social Media in 2008, and a study by awareness.com (2007) claims that $54 \%$ of organizations with more than 1,000 personnel utilize Web 2.0 technologies, as do $74 \%$ of companies with less than 500 employees. A recent report by Bracewell/de Lussanet/Camus (2008) also predicts fast growth of spending on Web 2.0 technologies (43\% per year,) reaching 4.6 bn USD in 2013 , while $56 \%$ of the corporations surveyed in the study say they have put Web 2.0 on their priority list.

\subsection{Customer-Generated Content}

Threadless in Chicago and Shirtcity in Barcelona are T-shirt retailers. OhmyNews is a Korean news service and Domino's pizza is the well known pizza giant in the US. What do these firms have in common? Besides the fact that all of these businesses are wholly or partly based on the web as distribution channel (something that millions of firms worldwide also do), all four have embraced Web 2.0 as a crucial element of their business model: they extract value from CGC by using Web 2.0-based approaches as intelligence agents and sources of innovation. A common aspect is the outsourcing of their product development and innovation proc- 
ess to their customers: Instead of developing products or services, they invite customers to do this, as well as to review and evaluate products created by their peers:

- Threadless invites creative customers to submit their ideas about T-shirts designs online; the submissions are evaluated by other site visitors and the best designs become part of the assortment, while the designer wins 2,500 USD in cash and merchandise as reward.

- Shirtcity offers customers the opportunity to create their own customized T-shirts and accessories and purchase them through the Internet. MyShirtcity (a customer-operated shop in the Shirtcity web site) allows customers or businesses to create their own products and collections and offer them online. The service is free: customers establish their shop and MyShirtcity does the rest.

- OhmyNews is a very influential Korean online newspaper written exclusively by about 60,000 amateur citizen journalists who submit and edit content. It has grown to become one of the most influential news media in S. Korea and is currently expanding internationally.

- Domino's Pizza, one of the old and traditional pizza brands, not only allows customers to order pizzas online, but also invites them to create customized pizzas. Customers can then give a name to their creation and make it available to others. One such customer-developed pizza has been ordered more than 80,000 times online within a short time.

These are examples of businesses capitalizing on the emerging desire of consumers to become co-developers and participate as equals in many aspects of the business activity: customers not satisfied with what businesses offer for mass consumption increasingly demand an individualized approach and customized products. Pro-active businesses have understood that involving customers in their internal processes (something that would sound like pure science fiction just ten years ago) improves relationships and increases customer loyalty; engaging the customer as innovation agent can also substantially reduces the company's new product development budgets and time-to-market.

There are several examples of such close relationships, pioneered mainly by large producers or service providers. SAP, one of the major players in the ERP software market, opened its doors a few years ago to external developers, embracing a large innovation-driven, interactive community. This approach has allowed SAP to solve very specific customer problems by creating technology services on a customized basis. A platform including blogs, wiki, discussion forums and portals, is part of this approach. AMD, a software developer, is also one of the pioneers in engaging users in developing, testing and improving its software solutions. Sun Microsystems follows the same tactics with the Sun Developer Network and Linux - this very successful operating system was developed exclusively by means of collaboration among specialists online. 
In all such cases, closing the distance between the company and the user is essential; customer forums, online communities, blogs, and a variety of open-source or user controlled applications are part of this effort. Executives like the CEO of Sun Microsystems, Jonathan Swartz, the CEO of Apple Computers, Steve Jobs, and the McDonalds Vice President, Bob Langert, post regularly on corporate blogs, encouraging customers to interact and freely express their feelings, suggestions or remarks about the company and its products.

\subsection{Collaboration with the Customer}

Information products are the area where online customer collaboration is easy, but the concept can easily be applied to tangibles, as the examples of Threadless, Shirtcity and Domino's Pizza - and hundred of other cases - demonstrate. Collaborative development and mass customization is increasingly attracting mainstream companies traditionally involved in mass production. Many such businesses are already testing methods of involving customers or their networks in product development, outsourcing their product design and even their advertising to talented consumers. Pioneers in this area are companies like Kleenex, Heinz, M\&M, the Spanish firm Portage, PepsiCo, the sport article manufacturer NIKE and its competitor Reebok, as well as the household furniture and décor chain IKEA.

Tapping customer communicational and advertising creativity is another area attracting business attention. This has to do with the decreasing effectiveness of traditional mass media approaches [2] and the increasing mistrust of customers in corporate communication and company claims. SONY and Sunkist with their Share the Orange initiative are indicative examples of a growing number of corporations partnering with talented amateurs who generate advertising concepts or even create TV commercials for them. The idea behind such partnerships is that advertisements and product endorsements by peers are not only much cheaper to produce, but also are perceived as being more credible and therefore more effective than those created by advertising experts.

\section{What is Web 2.0 (or Social Media)?}

Inspired by a new generation of Internet applications like the popular online encyclopaedia Wikipedia, online photo or video exchanges like Flickr, YouTube and Dreamstime, social networks like Facebook, LinkedIn and MySpace, business collaboration platforms like Slideshare, Joynet and Zimbrs, online communities like SecondLife, influential blogs like Engadget, Gizmodo or Techcrunch (the examples are countless), businesses and increasingly academics are paying more and more attention to the phenomenon. Marketers are becoming increasingly interested (Tancer 2007 [3]; Li et al. 2007): According to a study by McKinsey (2007b), 61\% of companies surveyed engaging Web 2.0 applications are somewhat satisfied 
or very satisfied with the returns on their investment. The most popular of the Web 2.0 tools were web services $(80 \%)$, collective intelligence $(48 \%)$, P2P networking (47\%), social networking (37\%), podcasts and RSS (35\% each), wikis (33\%) and blogs (32\%). In a similar study, Bughin (2008) calculated the proportional penetration of collaborative technologies: web services (67\%), P2P networking (28\%), collective intelligence (21\%), social networks $(19 \%)$, podcasts $(17 \%)$, blogs $(16 \%)$, RSS feeds $(14 \%)$, wikis $(13 \%)$, and mashups $(4 \%)$. A recent study of Scene7.com [4] confirms the popularity of Web 2.0 among businesses: Ninety-three per cent of the surveyed marketers working for companies selling products online (manufacturers, retailers, agencies and high-tech companies) plan to add Web 2.0 capabilities to their sites in the next six months.

In the heart of all developments described above we find a new term that has already earned the status of a buzzword: Web 2.0 or Social Media, the terms are often used interchangeably. The term Web 2.0 was officially coined in 2005 by Tim O'Reilly (O'Reilly 2005) who described it as a new form of collaborative Web, a "platform harnessing collective intelligence". Although most people would not disagree that Web 2.0 is the new generation of the web, an exact definition has not yet been universally accepted. Building on the original text of O'Reilly (2005), several definitions have been proposed. Hoegg et al. (2006) define Web 2.0 as "the philosophy of mutually maximizing collective intelligence and added value for each participant by formalized and dynamic information sharing and creation." The simple definition "Social Web" can be preferred, while some researchers describe the term by focusing on applications (Korica/Mauer/Schinagl 2006) or use the term "Social Software" (Castañeda 2007). Other definitions focus on the social or sociological aspects of Web 2.0 (Birdsall 2007; SpannerWorks 2007; Beer/Burrows 2007) or place emphasis on the technical aspects or applications allowing Web 2.0 functionalities (Facca/Lanzi 2004; Anderson 2007; McKinsey 2007b). Anderson (2007) defines the term Web 2.0 in two ways: His short description refers to a group of technologies that have become deeply associated with the term: blogs, wikis, podcasts, RSS feeds and so on, technologies contributing to a more socially connected Web where everyone is able to add to and edit content. The long definition is more complicated, touching on economics, technology and new ideas about the connected society. Nielsen (2007) proposes four components encapsulating what he considers as the Web 2.0 defining elements: a. "Rich" Internet Applications (RIA). b. community features, social networks, and user-generated content c. mashups (using other sites' services as a development platform) and d. advertising.

In general, the press has approached Web 2.0 as a social phenomenon, driving content and building personal relationships with the consumer rather than the marketer being in control. In this line, the key interest to marketers is how to effectively leverage Web 2.0 and derive value from social media-based tools; get real-time feedback on existing products or new product 
ideas/concepts, build "communities" among consumers around their goods, services or brand, leverage customer self-service, and have consumers collaborating on developing future product strategies (Parise/Guinan 2008).

Many observers and researchers agree that Web 2.0 is one of the important trends in technology (Cordington 2007; McKinsey 2007a); no general agreement as to the definition of the term can be found in the academic literature. It seems however that the variety of aspects involved in Web 2.0 require delineation of the term according to its different components. Constantinides/Fountain (2008) proposed the following definition: "Web 2.0 is a collection of open-source, interactive and user-controlled online applications expanding the experience, knowledge and market power of the users as participants in business and social processes. Web 2.0 applications support the creation of informal users' networks, facilitating the flow of ideas and knowledge by allowing the efficient generation, dissemination, sharing and editing/refining of informational content."

On the basis of this definition we propose a more detailed illustration of Web 2.0 along three main dimensions: Application Types, Social Effects and Enabling Technologies. These three elements are combined in the following image (see Figure 1):

Figure 1: The Three Dimensions of Web 2.0

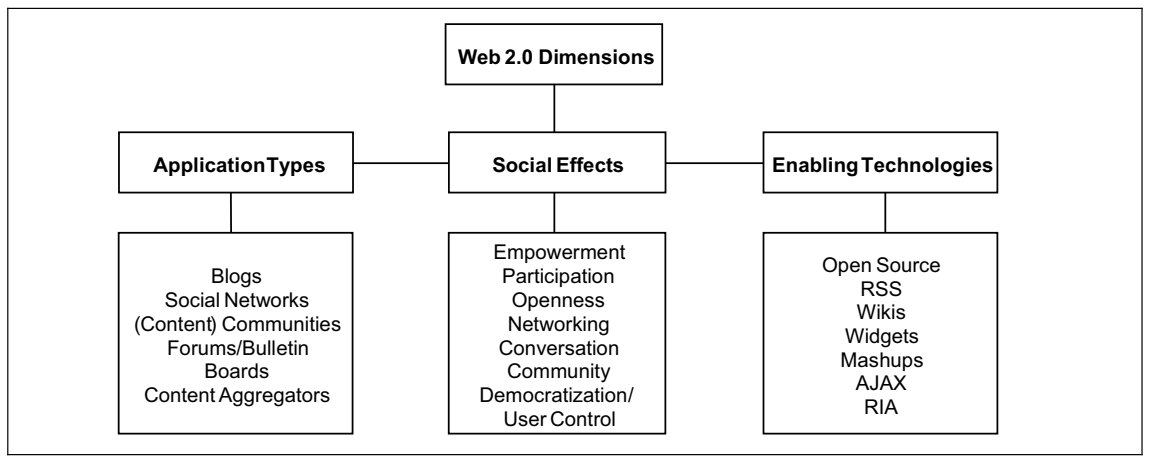

\section{Application Types}

There is a wide variety of application types fulfilling the criteria of the proposed definition. Applications can be classified in five categories:

- Blogs: Short for Web logs: online journals, the most known and fastest growing category of Web 2.0 applications (Du/Wagner 2006) often combined with Podcasts and Videocasts, i.e. digital audio or video that can be streamed or downloaded to portable devices.

- Social Networks: Platforms allow users to build personal web sites accessible to other users for exchange of personal content and communication. These networks also allow users 
to create contacts in all fields, from professional to personal ones (Dans 2007). Examples: www.myspace.com, www.facebook.com, www.hyves.nl, www.ning.com, www.meetic.es. According to McKinsey (2007c), social networks refer to systems that allow members of a specific site to learn about other members' skills, talents, knowledge or preferences. Pew and Internet [5] define this term as an online location where a user can create a profile and build a personal network that connects him or her to other users. Wikipedia [6] defines a social network as a service focused on the building of communities of people who share interests and activities, while Stroud (2008) sees the participants of social networks as people who are interested in exploring the interests and activities of others

- (Content) Communities: Web sites organizing and sharing particular types of content. Examples for applications of video sharing: www.video.google.com, www.youtube.com, www.etsylove.ning.com, photos sharing: www.flickr.com, social bookmarking www.digg.com, www.del.icio.us and publicly edited encyclopaedias: www.wikipedia.org and www.citizendium.org.

- Forums / Bulleting Boards: Sites for exchanging ideas and information, usually around special interests. Some examples are www.epinions.com, www.personaldemocracy.com, www.python.org.

- Content aggregators: Applications allowing users to fully customize the web content they wish to access. These sites make use of a technique known as Real Simple Syndication or Rich Site Summary (RSS). Examples are www.my.yahoo.com, www.google.com/ig. The user is a vital factor for all categories of Web 2.0 applications, not only as consumer, but also as content contributor. The term User-Generated Content (UGC) is often used to underline this special attribute of all above Web 2.0 application categories.

\section{Social Effects}

Enabling seamless generation of information and easy access to it is the key advantage of Web 2.0 applications. Copying, sharing, editing, syndicating, reproducing and re-mixing information are common practices in the Web 2.0 domain. The creation, sharing and dissemination of information results in democratization of knowledge and allows active participation by users as contributors, reviewers and editors. Users can easily create communities of special interests and further share their experience and knowledge, but also engage in a transparent conversation with the industry or politicians. The result is, as explained earlier, a unique form of customer empowerment allowing customers to affect as never before the market power structures and more importantly the shape of future marketing. Web 2.0 applications are becoming increasingly popular due to the advantages they offer to users (e.g. transparency, referrals, contacts with other users etc.) and their effect on customer power (Urban 2003, 2005). Interaction with peers triggers new customer needs (often for niche and highly personalized products) and alters buying attitudes. Nowadays, customer reviews posted in different forums or virtual communities, web blogs and podcasts are much more powerful and believable than 
expert product reviews (Gillin 2007). In fact, the influence of blogs and podcasts is increasing due to fast expansion of the audience and contributors [7]. However the usage rate of some Web 2.0 applications can be influenced by technical barriers requiring some higher degree of user sophistication (Tancer 2007). Another interesting social effect in online communities is the self-regulated quality assurance process observed (Hoegg et al. 2006). The social effects of the social media are, by and large, a fascinating research area and a field most likely to shape future consumer or even human behaviour.

\section{Enabling Technologies}

While most technologies involved in the Web 2.0 domain are not really new, there is a basic difference between Web 2.0 and Web 1.0, the previous generation of Internet applications, namely the fact that many of these applications - based on open source software - are the result of collaborative development and continuous, real time improvement (O'Reilly 2005; Constantinides/Fountain 2008). This fact places the application user in the chair of the application co-developer and has led to fast, low cost and efficient application improvement. Besides existing applications, the Web 2.0 movement is founded on some unique ways to use software applications and on new development techniques. The purpose of this article is not to examine this aspect of Web 2.0, but below there is a short description of the most important enabling technologies and development tools applied in this domain.

RSS is short for Rich Site Summary or Really Simple Syndication, a way to syndicate and customize online content. Services like Google Reader, MyYahoo, Bloglines, Netvibes, Alesti etc., allow monitoring of consumers' favourite blogs, efficient customization of the news (Dans 2007) or other online content of interest to the user.

Wiki are applications allowing collaborative publishing. They are multi-author edition pages in which some authors can jointly collaborate to edit the web page and elaborate on specific documents. Wikipedia, considered to be the biggest encyclopaedia today, was developed and continues to grow through a wiki tool (Dans 2007).

Widget is a generic term for the part of a Graphical User Interface that displays information and allows users to interface with the application and operating system in different ways.

Mash-ups are aggregators of content from different online sources to create a new service. $A J A X$, short for Asynchronous JavaScript and XML, is a web development technique used for creating interactive web applications. This technology allows continued re-charge and actualization of web pages, facilitating navigation within sites that require a large quantity of data, such as maps, photos, videos, etc. (Cerezo 2007).

$R I A$, Rich Internet applications (RIA), are Web applications that have the features and functionality of traditional desktop applications 


\section{Web 2.0 and Retailing: E-tailing in the Social Internet}

\subsection{Web 2.0 as Enabler of Internet Retailing}

Grewal/Iyer/Levy (2004) observed that " [...] no other innovation has received as much attention from retailers, manufacturers, consumers and the general public as has been accorded to Internet retailing, or e-tailing. Indeed, no other form of intertype competition threatens to upset traditional retailing more than Internet retailing". All statistics point to outstanding growth of Internet retailing in the past few years. Estimations from different sources (i.e. e-marketer, Forrester) show that Europe's online retail market is growing at a yearly rate of about $37 \%$, while the US online market is growing in the low 20s (Dellner 2007).

Figure 2: Online Retail Sales Estimations in Europe (in m EUR)

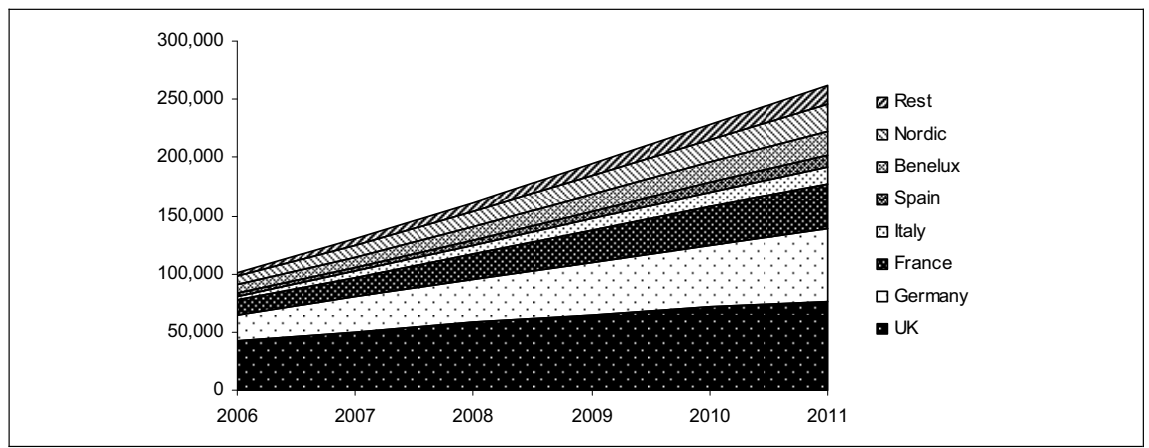

Source: Dellner (2007) based on Forrester Research.

Figure 3: Online Retail Sales Share in Europe (Estimations)

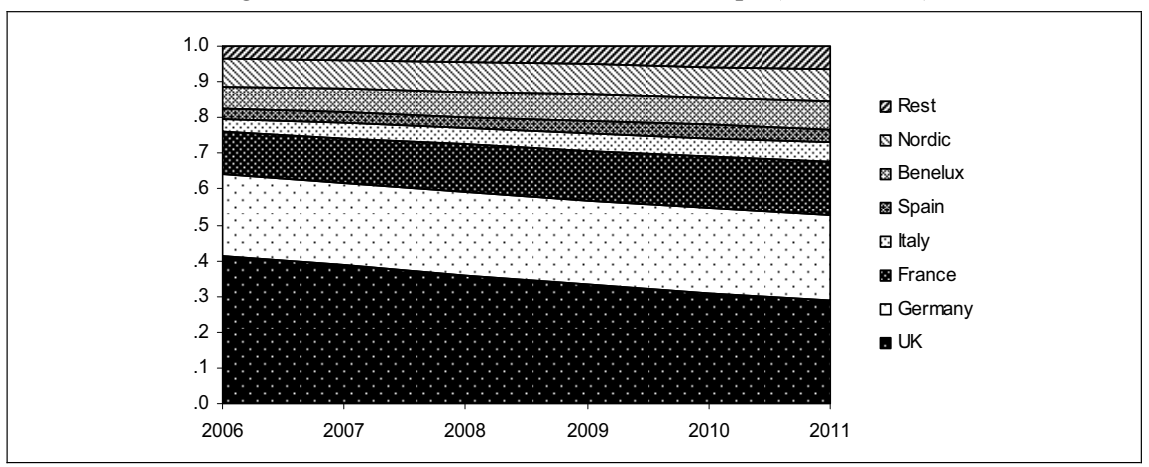

Source: Dellner (2007) based on Forrester Research.

According to Forrester Research, the number of Europeans shopping online will grow to 174 $\mathrm{m}$ with an average yearly net spending of 1,500 EUR. With these numbers, European ecom- 
merce could reach 263 bn EUR in 2011, with travel, clothes, groceries and consumer electronics all above the 10 bn EUR per year mark. According to Dellner (2007), the highest growth rates are likely to manifest in countries with faster increasing rates of Internet penetration (e.g. Portugal or Greece). Nevertheless, the largest volumes of online retailing are realized in the United Kingdom, Germany and France. The most popular categories for online retailing in Europe are quite similar to those in the US. Leisure and travel products lead the ranking, followed by books and CDs, apparel and home products, and grocery shopping, particularly in the UK (Dellner 2007). Figure 2 shows the online retail sales estimations for different countries and Figure 3 the relative share of different countries.

Internet retailing does not escape the Internet technological trends, and e-tailing as a retail format has moved quickly through its life cycle paralleling the technology change. We agree with Grewal/Iyer/Levy (2004) when they say that the observations and content regarding the actual state of internet retailing may be debatable or obsolete in a very short term.

As we noted earlier, one of these technological and conceptual changes, not only in Internet retailing, but in human-system interaction, is the emergence and the mushrooming growth of Web 2.0 concepts and tools. In fact, according to Bracewell/Lussanet/Camus (2008), the main trends and challenges of online retailers are related to Web 2.0 concepts as collaborative merchandising or mobile comparison shopping.

Figure 4: Internet Retailing Enablers and Limiters

\begin{tabular}{ll}
\hline Enablers & Limiters \\
\hline - Product category & - Lack of trial \\
- Information availability & - Lack of interpersonal trust \\
- Access to price information & - Lack of instant gratification \\
- Novelty & - Customer service issues \\
- Accessibility & - Loss of privacy and security \\
- Convenience & - High economies of scale \\
& - Lack of stable consumer base \\
& - Poor logistics \\
& - Lack of experience \\
\hline
\end{tabular}

Source: Grewal/Iyer/Levy (2004).

To evaluate the impact and potential effects of Web 2.0 concepts and tools, the framework of Grewal/Iyer/Levy (2004) for analyzing Internet retailing phenomena can be a good starting point. These authors identify different factors that enable or limit Internet retailing growth. The question is whether Web 2.0 as a technological and conceptual framework can stimulate enablers and reduce limiters to Internet retailing growth. While some of the enablers and limiters are not dependent on Web 2.0 functionalities, Web 2.0 as a new element can have an im- 
portant effect on them. Figure 4 shows the enablers and limiters proposed by Grewal/ Iyer/Levy (2004).

By and large, some enablers have been reinforced; through Web 2.0 applications, consumers can access richer information, not only due to the fact that this information can be of higher quality (e.g. using RIA or mashups applications in web sites) or more trustworthy (e.g. other users' opinions from a virtual community), but because the information can be easily processed (e.g. using different applications for comparing prices or product features) and edited. Information accessibility, availability, quality and comparability are clearly reinforced. At the same time, e-tailers have additional tools and resources in place for a better shopping experience, improving originality and expanding consumer experiences on the web. Moreover, more products are bought online due to the additional option of customization.

In addition, Web 2.0 tools can reduce risks and uncertainty of shopping online. Their main advantage is the new interactive and social dimension. This interaction both with the e-tailer personnel and other consumers can enhance consumer confidence and trust (e.g. live agents, virtual communities) and improve consumer service (e.g. chat or live agents, VOIP - Voice over IP: Internet-based telephony - applications). At the same time, the shopping experience is improved both by richer stimuli and by different tools that allow a more enjoyable and easier interaction with the web site.

\subsection{Implementation of Web 2.0 in Retail}

As noted above, Web 2.0 could give a new impulse to Internet retailing and in some cases alleviate some of its negative dimensions. The effects of Web 2.0 in retailing can be broken down into three dimensions (Jain/Ganesh 2007a): Content parameters, collaboration parameters, and commerce parameters (see Figure 5).

Figure 5: Implementation of Web 2.0 in Retail

\begin{tabular}{|c|c|c|}
\hline Content Parameters & Collaboration Parameters & Commerce Parameters \\
\hline $\begin{array}{ll} & \text { Unique user experiences (RIA } \\
\text { driven). } & \\
\text { Dynamic user help (peer-to-peer or } \\
\text { central). } \\
\text { - } \\
\text { Data Feeds (RSS, ATOM, HML, JS). } \\
\text { - } & \text { Podcasts/Vodcasts. } \\
- & \text { Search (semantic). }\end{array}$ & $\begin{array}{l}\text { Customer peer-to-peer network, } \\
\text { collective intelligence (blogs, } \\
\text { wikis, discussion forums, user } \\
\text { reviews, tagging etc.). } \\
\text { Collaborative product customiza- } \\
\text { tions. }\end{array}$ & $\begin{array}{l}\text { - } \begin{array}{l}\text { End user product customizations. } \\
\text { - }\end{array} \text { Contextual shopping help (live } \\
\text { agent chat). } \\
\text { - } \quad \text { Voice based shopping help (VolP). } \\
\text { - } \quad \text { Comparison shopping (across } \\
\text { brands, end user recommenda- } \\
\text { tions. }\end{array}$ \\
\hline
\end{tabular}

Source: Jain/Ganesh (2007a).

Content parameters are related to tools and techniques, allowing a better and richer information environment. For example, RIAs (Rich Internet Applications) like FLEX allow a higher 
quality presentation format with an easier and more user-friendly interface that enhances the customer experience. The same happens with RSS feeds, podcasts, videocasts or mashups.

Collaboration parameters refer to applications that allow consumers-retailer interaction and participation of consumers and other agents in product or services productions (see the example of SAP or AMD at the beginning of this chapter). Finally, commerce parameters are related to functionalities that can support consumer choices and/or give a higher value to the chosen option. For example, offering some kind of shopping assistant or a complementary support service through voice or chatting tools.

\section{The Web 2.0 as a Marketing Tool}

A basic issue for firms wishing to engage Web 2.0 as a Marketing tool should be the position it takes in relation to the rest of the marketing programme. The literature available on this issue is focused on the impact of Web 2.0 applications on corporate processes (Craig 2007; Yakel 2006), the importance of online communities for corporations (Du/Wagner 2006; Korica/Mauer/Schinagl 2006; Swaine 2007) or issues regarding the effects of these new technologies on business (Karger/Quan 2005; Biever 2006; Deshpande/Jadad 2006; Boll 2007). Non-academic sources also provide plenty of evidence as to how corporations integrate Web 2.0 applications into their operations (DeFelice 2006; McKinsey 2007b). An increasing number of studies suggest that corporate interest in the Web 2.0 domain keeps growing, and more and more firms are introducing different forms of social media into their daily business routines as well as their marketing strategies (Cymfony 2006). Whereas marketing with traditional communication media such as newspapers, television, and news web sites was about delivering a message, marketing with social media is about building a relationship and conversation with others. Marketing by means of social media is therefore not just about delivering a message, but also about receiving and exchanging perceptions and ideas with the customer (Drury 2008). This requires a different approach and organization by marketers. From the marketing perspective, it is necessary to identify the strategic position of Web 2.0 in the context of the overall marketing strategy of a firm and what the basic requirements are for successful engagement of Social Media as marketing tools. The relation of Web 2.0 to the rest of the marketing effort is illustrated in the following image (see Figure 6) indicating the position of Web 2.0 in relation to the overall marketing plan. According to this approach, Web 2.0 must be seen as the pinnacle of the marketing process, the top of the marketing strategy pyramid.

STAGE 1: The basis of marketing strategy should be the quality of the company products and services. Quality must reflect the company's vision, market image and market positioning. Failing to deliver the expected product quality in the era of Social Media is risky because the consumer is able to find out the truth (i.e. whether the value promised by the firm is actually 
delivered) by getting in touch with other users or product reviewers. Quality systems and control mechanisms are very important strategic components in this stage.

STAGE 2: Refers to the creation and maintenance of a market-oriented organization that will be able to support traditional, as well as online marketing activities. We should remember that many of the traditional organizations that adopted e-commerce often had difficulties in adapting their organization and reaching the level of sophistication required to operate online. On the other hand, the reputation and competitive advantages of traditional business is a valuable asset and source of goodwill for online business.

STAGE 3: Creating a market-oriented organization supporting traditional and online marketing activities is essential in order to establish a successful online presence in the form of a web site. For retailers, it is important to understand that the web site can play a number of different roles: Informational, promotional, relational, educational or transactional. Assigning the right roles to it is imperative for online business to become a valuable part of the overall marketing programme (Constantinides 2002).

STAGE 4: Having an impeccable online presence will allow firms to move to the next stage, namely involving Web 2.0 in their marketing. Since the corporate web site is the first (and often the only) place that online consumers will turn to after they are informed about the firm, their experience of the web site must be of the highest possible quality. If this is the case, the firm can proceed in identifying and selecting the proper Web 2.0 tools for its marketing.

Regarding the step from Stage 3 to Stage 4, Nielsen (2007) suggests that while a modest 2.0 infusion can be beneficial, advanced features are rarely the most important contributor to good user experience or profitable web sites. For Web 2.0-enabled firms, simplicity really pays off and synergy with the Web 1.0 environment is vital. Therefore, before investing in " 2.0 " features, a company must make sure that their " 1.0 " interface is operating perfectly

Figure 6: The Marketing Strategy Pyramid

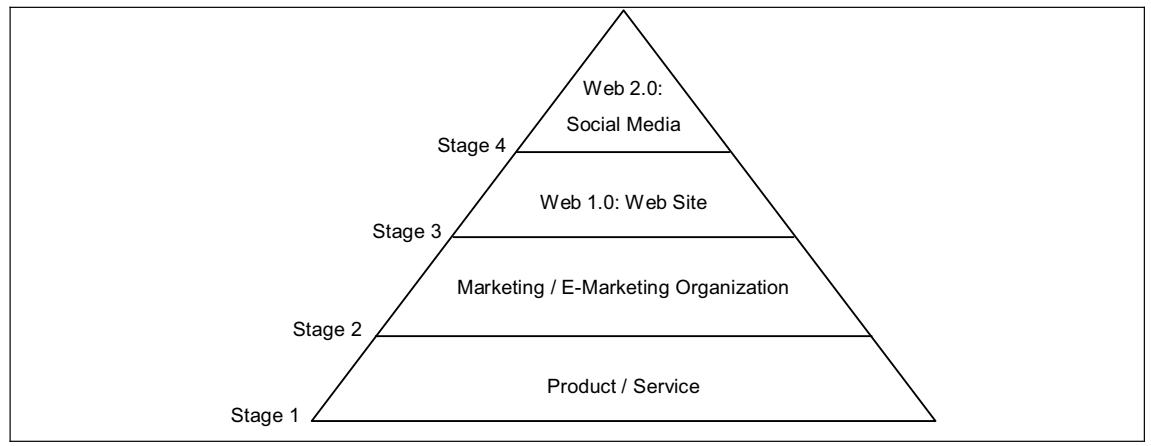




\section{Web 2.0 in Practice: Effects on the Customer Decision-Making Pro- cess}

In order to integrate Web 2.0 applications into the corporate commercial strategy, marketers should firstly understand its effects on the consumer's decision-making process, identify the sources of customer value, and the customer motives for using these applications. In the Web 2.0 era, customer preferences and decisions are increasingly based on inputs provided by parties beyond the control of online marketers: peer reviews, referrals, blogs, tagging, social networks, online forums, and other forms - uncontrollable by marketers - of user-generated content.

Based on Kotler (2003) and Constantinides (2004), in Figure 7 we see Web 2.0 as a new marketplace component, further complicating the time-honoured textbook buying behaviour process described in the inputs-processing-response model. The A and B elements represent the traditional influencers of consumer behaviour: Conventional marketing mix influences as controllable stimuli (A), and uncontrollable personal influences stimuli, such as demographic, cultural, perceptual, economic, etc. (B). The emergence of the Internet, its adoption and use as communication and transaction medium by marketers and users, adds two more inputs and influencers of buying behaviour to the model: the controllable Web Experience factors (C), such as usability, interactivity, trust, aesthetics and online marketing mix (Constantinides 2004), and Web 2.0 influencers (D) considered as non-controllable by marketers.

Figure 7: Factors Influencing the Consumer's Decision-Making Process

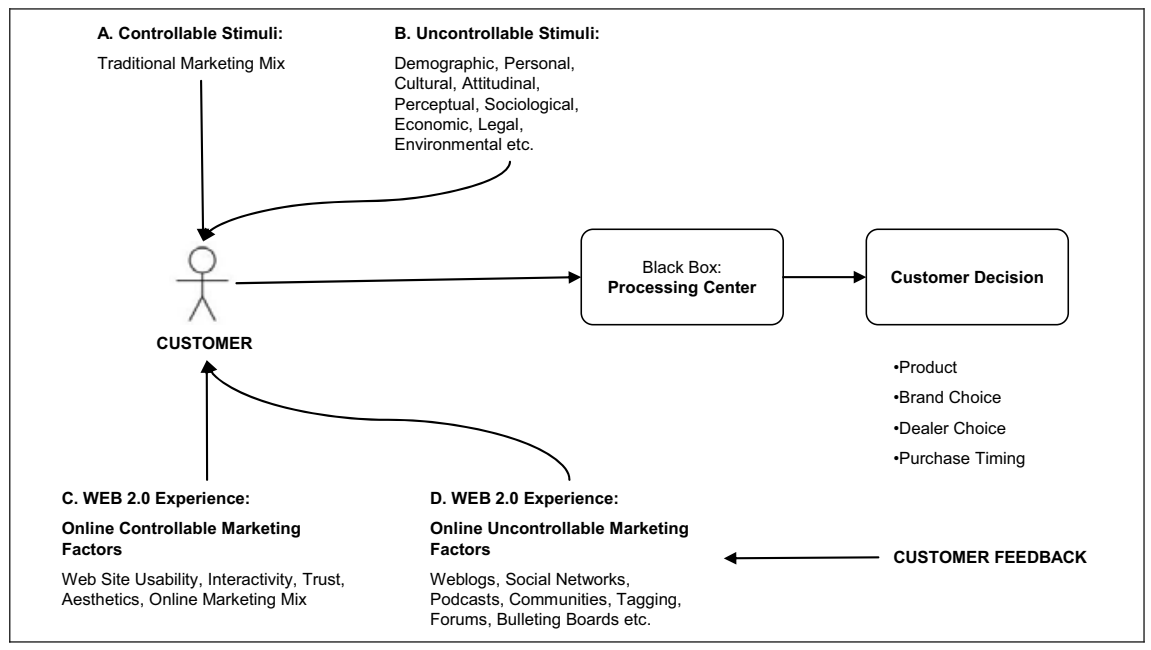

Source: Constantinides/Fountain (2008). 
McKenna (1997) proposed the term Real-Time Customer, based on the premise that information technologies enable companies to conduct real-time dialogues with their customers. These conversations should then facilitate long-term relationships with current and potential customers. With the advent of Web 2.0 tools, the Real-Time Customer is a fact: marketers can not only communicate with customers through traditional broadcast advertising, but also can (and should) empower consumers to participate in marketing activities that were previously "one-way": branding, product development, product evaluation, and customer service. This is important as the basis of a transparent and pleasant image (Moral 2007).

Moreover, web-based customer communities can provide a 50\% faster turnaround time and cost reduction in obtaining effective product ideas and feedback compared to traditional market surveys and focus groups. In addition to answering direct questions, it is the customer-tocustomer trusted conversation that yields some of the most interesting insights (Parise/Guinan 2008). This new phenomenon of information crowd generation is known as "crowdsourcing", as an evolution from outsourcing. As customers increasingly take over typical company activities, corporations will be forced to work much more "on demand" (Moral 2007): market only the t-shirts demanded by their clients (www.lafraise.com), launch advertising campaigns developed or approved by their customers (www.fon.com), or create assortments suggested by users like the furniture retailer muji.net.

\section{Engaging the Web 2.0 as a Marketing Tool: The Passive and Active Ways}

The process of adopting Web 2.0 tactics as part of the company marketing programme requires new thinking and new tactics; traditional push marketing methods are incompatible with social networking ( $\mathrm{Li}$ et al. 2007). Lack of experience in engaging social media as marketing communication tools means, that, for many pioneers, this is still a trial-and-error process. In this respect there is a considerable knowledge gap on the real nature and importance of Web 2.0 and its added value for marketing strategy.

Most knowledge on the role of Web 2.0 applications as marketing tools is primarily based on anecdotal evidence. This evidence (with several examples mentioned earlier) also suggests that, paradoxically, the majority of firms pioneering in engaging Web 2.0 as a marketing tool are large corporations. Based on field experience, this chapter will classify the main paths marketers can follow in order to extract value from the Web 2.0 domain. Marketers could influence the customer decision-making process by means of Web 2.0 tools in two principle ways: Passive and active. 


\subsection{The Passive Way or Listening-In: Using the Web 2.0 as an Intelligence Source, i.e. as a Source of Customer Voice and Market Information}

Marketers can learn a lot by listening to the customer's voice, and they have done this extensively in the past by using, for example, surveys and focus groups. Today, marketers can do the same by monitoring the social media space: blogs, podcasts, forums, and online communities. Listening to the customer is especially important in order to identify market experiences, new market needs, and hear early warnings about product problems indicating the need to improve, modify or drop products. What customers say online is vital, and vital sharing of customer experiences can lead to success or failure of brands and products and seriously disrupt costly marketing actions. "Listening-in" to the customer's voice provides companies with early warnings of customer dissatisfaction and allows for fast corrective reactions. Furthermore, the online customer voice can provide precious and high quality information at a fraction of the time and cost required in using traditional market research for this purpose.

The important question is how to find and tap the customer's voice, but there are already different options available. Web sites like the TIMES Online List, with the 50 best business blogs [8], the Corporate Responsibility Group [9] or Bized [10], are examples of useful online sources of consumer voice. Besides this, marketers must trace discussion forums, communities or even video sharing sites where exchange of information about the firm's and competitive products takes place. There are several specialized tools and search engines that could help marketers in locating and gathering this type of content. Nielsen Buzz Metrics, a commercial service monitoring several millions of blogs, can provide marketers with a lot of information as to what is discussed online and even what is said about the company or its products. Specialized classification tools like Technorati, blog search engines like BlogPulse or the "index aggregator" TalkDigger are easy to use and offer low-cost alternative solutions.

\subsection{The Active Way: Using Web 2.0 Applications as a PR, Direct Marketing and Customer Influence Tool, as well as a Means of Personalizing the Cus- tomer Experience and Tapping Customer Creativity}

\subsubsection{Using Web 2.0-Based Applications as PR and Direct Marketing Tools}

Several businesses are actively engaged in dialogue with the customer by launching their own corporate blogs and discussion forums. Business executives like Jonathan Swartz, CEO of Sun Microsystems, Steve Jobs, CEO of Apple Computers, and McDonalds Vice President Bob Langert post daily on their corporate blogs, encouraging customers to interact and freely express their feelings, ideas, suggestions or remarks about their postings, the company or its products. A widely applied variant of this strategy (initiated by Microsoft back in 2003) is to encourage company employees to become publishers of content themselves in corporate blogs 
and forums. This approach requires openness and trust in employee capabilities on the part of the firm (McAfee 2006). Censoring of employee content is counterproductive; a good practice is to agree in advance on the basic principles and possible limitations on corporate blogging. An alternative and more simple way to engage social media as a PR tool is to use content communities -like the video sharing sites YouTube, GoogleVideo and others- as broadcasting media for distributing advertising material. Commercials uploaded to these sites have the potential to be viewed by thousands or even millions of viewers or virally distributed among users at practically no cost.

\subsubsection{Engaging Web 2.0 Personalities for Customer Influence}

This approach is based on proactively engaging the online sources of customer influence (blogs, podcasts, online forums etc.) as customer influence tools. This requires identifying, reaching and informing the "New Influencers" (Gillin 2007) about the firm, its brands or (new) market offers. The objective is to attract the attention of leading blogs or users' forums so that they review, discuss, comment on or even recommend using the firm's products. Besides obtaining and engaging these sources as company advocates, marketers can also reach very specific audiences by advertising in well-selected blogs and special interest networks or communities. This enables immediate access to target markets, even to very specific market segments at a fraction of the costs required by traditional media. Finding the major influencers per product or product category requires some effort, but the tools mentioned in the previous section are also suitable for this purpose.

\subsubsection{Engaging Social Media for Personalizing the Customer's Online Experience}

The first step retailers should take is the creation of a social web site allowing users to interact with the firm and with the rest of the site visitors. Wang et al. (2007) suggest that the use of "social cues" (i.e. language, social role, voice, interactivity) by virtual retailers yields a competitive advantage that provides consumers with enhanced perceptions of human connection and the formation of emotional bonds; social applications induce perceptions of web site sociality, leading to increased pleasure and arousal, both of which positively influence flow, hedonic and utilitarian value, and patronage intentions. Moreover, this social, cue-induced arousal improves pleasure, mainly for consumers who are involved with the product category. Regarding demographic aspects, the influence of arousal on hedonic value is stronger for women, flow does not lead to pleasure for older consumers, and utilitarian value is less relevant for this older group than for the younger one. This approach could lead to closer ties between the customer and the firm by offering customers the opportunity to personalize their online experiences in an environment created and controlled by the firm itself. Brick-andmortar firms like Nike, Disney, Coca Cola, TIME magazine, The Hearst Media, etc., are al- 
ready experimenting with such tactics as part of their direct marketing: seeking communication, interaction and customer feed back. They do this by introducing web sites based on usergenerated content, encouraging customers to customize them to their needs, and often create their own social networks.

\section{Tapping and Disseminating Customer Creativity in the Form of Advertising Concepts or Product Reviews}

Tapping customer advertising creativity is likely to increase customer goodwill and customer advocacy. SONY, Frito-Lay's, Sunkist and Coca Cola are indicative examples of a growing number of corporations partnering with talented amateurs who review their products, generate advertising concepts or even create TV commercials for them. The idea behind such partnerships is that advertisements created by peers are perceived as being more credible and therefore more effective than those created by advertising experts. There is some evidence that this is often the case: According to a Bizrate survey (2007), 59\% of web users consider customer product reviews - a concept initiated by Amazon and widely applied now - to be more reliable than those of experts. A study by Deloitte Touche USA indicates that $62 \%$ of US consumers read consumer-generated online reviews and $98 \%$ of them find these reviews reliable enough. Besides, $80 \%$ of these consumers say that reading peer reviews has affected their buying intentions. In a study conducted by Carlson Marketing, $85 \%$ of consumers say that they recommend a company with which they have a trusted relationship to others. The trust of consumers in peer rather than expert opinion is based on the perception that the former is more reliable because it reflects the genuine feelings of the product user, like themselves. This strategy requires either creating Web 2.0-type corporate web sites where users or customers can place their own product reviews or creating communities and Forums/Bulletin boards where customers can express their views.

Parise/Guinan (2008) carried out a study where some firms were interviewed to evaluate the use of web-based customer communities tools as to their efficiency as marketing strategies. The companies utilized such communities in order to solicit product ideas and product feedback. One of the leading companies in the greeting card and gift business had been using a customer community successfully to verify and explore ideas that were currently under development by its product development department. Conversations among community members ranged from discussing colours and designs that should be used on a greeting card to selecting what gifts and price ranges were more appropriate for a high school graduation. Community members were also asked to keep a virtual journal where they recorded and ranked marketing materials that they received from the company. Additionally, the company used the online community to learn more about the customers themselves. Community members were asked to upload and share their pictures and provide insights about their lifestyles, hobbies, and needs. This resulted in the company gaining valuable insights into consumer behaviour, reac- 
tions to new products and ideas, as well as the effectiveness of the company's marketing materials, all at a very low cost and effort.

\section{Making the Customer a Co-Producer}

The second variant of the strategy of utilizing customer creativity is capitalizing on growing customer individualism by making online tools available that allow partial or full customization of the company's products. Companies like Kleenex and photostamps.com allowing consumers to customize their products, Heinz invites customers to create their own personalized labels for their ketchup bottle, and M\&M make it possible for customers to select their favourite colours of sweets and have a personalized message printed on it, Portage.es in Spain allows users to decorate the bags they purchase with their photos. Pepsi co. invites fans to design their soft drink cans in the Design Our Pepsi Can Contest. The best idea is adopted as the new monthly packaging of the Pepsi can. The sports article manufacturer NIKE offers similar tools to customers allowing them to customize the sport shoes they order online. Its competitor, Reebok, uses collaborative development in a different way, i.e. by reducing the development cycle of new sport shoes by engaging online collaboration involving suppliers, laboratories, retailers and personnel. This can not only reduce the development costs, but in some cases can also reduce the usual 18-month development cycle to only ninety days. Another way of using social media for Reebok is to operate a shop in the well-known online community Second Life, which offers virtual visitors the opportunity to customize products in a variety of colours and styles far beyond what they are able to order in retail stores. As a final example, we would like to mention the popular chain of household furniture and décor - IKEA who recently launched an online campaign called "Everyone is Designer", encouraging customers to create their ideal living space.

Figure 8: Web 2.0 Applications as Marketing Tools

\begin{tabular}{l|c|cccc}
\hline \multicolumn{1}{c|}{ Marketing Objective } & Passive & \multicolumn{3}{|c}{ Active } \\
\cline { 2 - 6 } Application Type & Listening in & $\begin{array}{c}\text { PR and direct } \\
\text { marketing }\end{array}$ & $\begin{array}{c}\text { Reaching the } \\
\text { new influencers }\end{array}$ & $\begin{array}{c}\text { Customer advertising } \\
\text { concepts and product } \\
\text { reviews }\end{array}$ & $\begin{array}{c}\text { Customer as } \\
\text { co-producer }\end{array}$ \\
\hline Web logs & $\mathrm{XXX}$ & $\mathrm{XXX}$ & $\mathrm{XXX}$ & $\mathrm{XX}$ & $\mathrm{X}$ \\
(Content) communities & $\mathrm{XX}$ & $\mathrm{X}$ & $\mathrm{XXX}$ & $\mathrm{XXX}$ \\
Social networks & $\mathrm{X}$ & $\mathrm{XX}$ & $\mathrm{X}$ & $\mathrm{XX}$ & $\mathrm{XX}$ \\
Forums/Bulletin boards & $\mathrm{XXX}$ & $\mathrm{X}$ & $\mathrm{XX}$ & \\
Content aggregators & & $\mathrm{XX}$ & $\mathrm{XXX}$ & & \\
\hline
\end{tabular}

Note: XXX: very suitable; XX: suitable; X: suitable sometimes.

Figure 8 suggests that certain application types are more suitable than others for achieving certain marketing objectives. In the event of the passive use of Web 2.0, firms will should locate the sources of customer input and identify an efficient way to tap and analyze the information. There are already several commercial organizations specialized in this type of data mining. In the active use of Web 2.0 cases, firms will have to develop an intelligence system 
and network for their online PR activities and create their own Web 2.0 applications allowing for product customization and co-creation.

Utilization of the above passive and active tools depends on the abilities, resources and characteristics of each company. A substantial number of retailers belonging to the small and medium enterprise category often struggle to keep up with even the more traditional online web activities, such as having a presentable and truly interactive web site; lack of financial and human resources and lack of time are usually serious barriers for such firms (Van der Veen 2004). The proper way for most retailers to pursue marketing objectives by means of Web 2.0 applications is to proceed by addressing a number of critical issues:

- A basic condition is: Willingness to invest: In order to improve the traditional online presence, retailers interested in using the social media must be willing to allocate some financial and human resources to that activity.

- Review options: Reviewing different new marketing tools (see Figure 4) and deciding which of these methods are proper and feasible to apply according to the company's resources and capabilities.

- Engage social media as passive marketing tools: Given the small size and often limited market coverage of retailers, there is little chance that most of them will be able to catch any substantial online customer murmur about their products through the buzz method. Listening-in to the user's voice makes sense if the company or brand is known. Retailers can, however, listen to the voice of the market in order to be informed not only about changing consumer needs and trends, but also to hear the customer's opinion about competitors or products. Web logs and online forums are the most important potential sources of such information, followed by the content communities and social networks.

- Engage social media as active marketing tools: Depending on the company size, market coverage and the marketing objectives, a retailer could create and make available online tools that allow users to interact with the firm and other customers, customize their experience, express their creativity either in advertising copies or design of new products, integrate good ideas from customers into the mainstream marketing program, and so on.

The framework is based on practical experience so further research is necessary to confirm the relative suitability of different application types to achieve the different objectives and refine these applications.

\section{Web 2.0 Adoption: Facts and Prospects}

Assuming that Web 2.0 could improve e-tailer marketing and the exchange relationships with the customer to a large extent, it is interesting to look closer at the degree of adoption of Web 
2.0 applications by the industry. A recent study at Infosys by Jain/Ganesh (2007a, b) (see Ganesh 2007 , too) looks closely at this issue.

According to this study, Web 2.0 adoption is not yet a fact in this sector. The most popular features are RIA- based user interfaces, static mashups (e.g. third party maps as Google maps) and qualitative and quantitative product reviews. Tools as blogs, discussion forums, data feeds, live agent chat, podcasts, videocasts or end user products and service customizations are scarce. Functionalities such as wikis, synchronous chat, collaborative product customizations, comparison shopping across retailers, end user contributed contents of VOIP [11] consumer-based support are the least adopted applications.

Figure 9: Web 2.0 Adoption for Different Retail Sectors

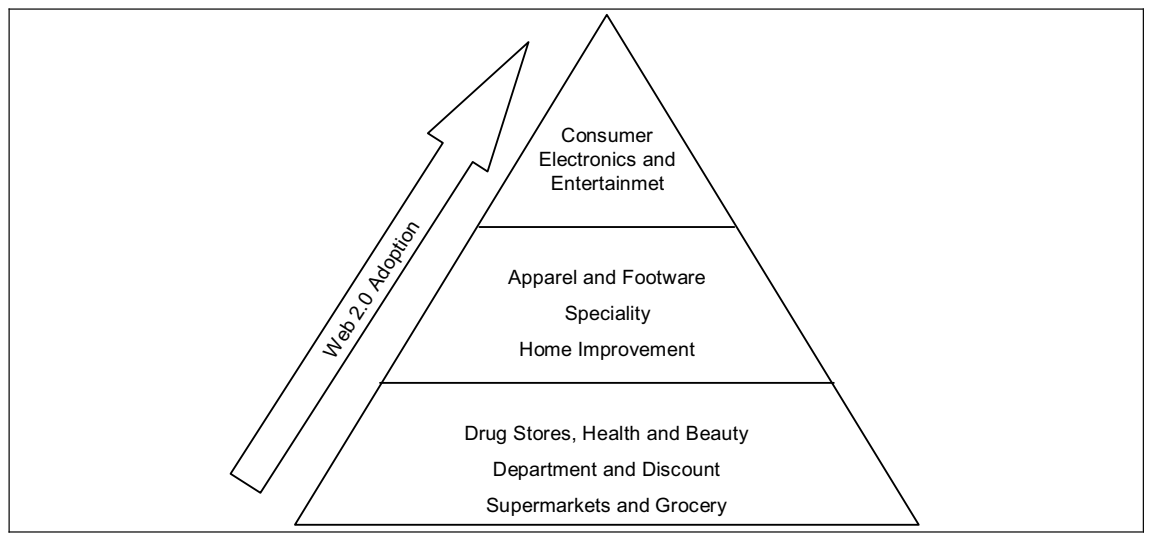

Source: Jain/Ganesh (2007b).

The adoption rate also varies for different types of retail sectors. As we can see in Figure 9, consumer electronics and entertainment is the sector with a higher adoption of Web 2.0 tools, while supermarkets and grocery are light users. While retailer size and resources influence the adoption of these tools, it is important to include two remarks here. Firstly, retailers with low commitment in online business (i.e. many limitations in their Web 1.0 situation) are less likely to make a commitment for Web 2.0. Secondly, it seems that even top retailers are far from incorporating Web 2.0 applications into their marketing plans. As mentioned earlier, most initiatives come from large traditional producers of consumer products or click-only online retailers.

If we consider the benefits and potential of Web 2.0 for different dimensions of the retail sector and the fact that most e-tailers have not taken advantage of these new and widely available functionalities, it is necessary to rethink the way that these benefits could be realized. 
Jain/Ganesh (2007b) suggest an interesting and intuitive kind of "roadmap" to implement Web 2.0 functionalities. They differentiate between short-term implementations (could be adopted in less than three months), medium-term implementation (adopted in three to six months) and finally, long-term technologies implementation that refers to functionalities that need more than six months for their application. Their classification of "potential implementation" depends on the technological maturity of the technology that supports the functionality, the resources required for implementation, and the time that a retailer needs to assess the success of the various actions.

\section{Limitations of the Study and Issues for Further Research and Con- clusions}

Every study on new social or commercial phenomena faces a typical situation, namely a shortage of academic references, and often an abundance of non-academic ones. This is certainly the case for the Web 2.0 issue and the authors of this paper have also been confronted with this reality. Whenever non-academic references have been used in this paper, the selection of sources was careful and based as much as possible on the reputation and validity of the source. Lack of concrete academic scrutiny and scientific evidence is a warning to businesses to be cautious when engaging Social Media as marketing tools: blind imitations and haphazard implementation can lead to disappointments and misjudgements as to the real value of these tools. In this respect, several of the ideas and models presented in this introductory study will become the focus of further study and empirical analysis as hypotheses to be tested. Most emphasis in the immediate term will be placed on the empirical testing of the parameters in the model presenting the Web 2.0 applications as marketing tools. Finally, the sometimes normative style of the paper is partly the result of the above mentioned lack of scientific underpinning and is partly motivated by the need to establish some bases for further research and debate. Considering the serious social and commercial effects of the Social Media, this debate is urgently needed.

This introductory article presents a comprehensive picture of the theoretical and practical debate around the new generation of Internet applications and tools usually referred to as Web 2.0 or Social Media, with special attention to implications for the retailing branch. It identifies the main parameters of the issue, one of the most important being the customer empowerment emanating from the wide adoption of Social Media by the online consumer. The article reviews the literature around the topic and proposes a definition of Web 2.0 touching on all important dimensions of the concept: the application types, social effects, and enabling technologies. 
A review of the adoption status of Web 2.0 applications by the retail sector indicates that only a limited number of retailers have adopted one or more Social Media-based approaches to their marketing strategy. Paradoxically, the pioneers in this area are traditional producers of branded mass products and online retailers, while most of the traditional retailers are still not involved in any substantial form of Web 2.0-based marketing. With regard to the first type of adopters (producers of mass-branded products), we could mention that the main motive of these firms to explore Web 2.0 terrain is the fact that consumers become not only more powerful, but also increasingly quality-conscious and negative towards mass products. Furthermore, marketers realize that traditional forms of marketing become increasingly ineffective when consumers trust other consumers much more than corporate communication. The article explains the basic strategic issues around Web 2.0, and particularly its position in relation to the overall marketing strategy. It argues that implementing Web 2.0 strategies is the last step of the strategic marketing process, after a number of more basic marketing issues have been addressed in an adequate manner. This concept is illustrated in the Marketing strategy pyramid.

The article also examines the effects of the Social Media on the consumer decision making process, identifying them as a new uncontrollable factor of the Inputs-Processing-Response equation. Attempting to control the Social Media makes no sense; the best strategy a firm can follow is to identify ways of utilizing such applications to its own benefit. There are two main strategies available: using the Social media in a passive way (as a channel of listening to the voice of the customer), or in an active way: as Public Relations tools, as a means of offering customers' superior experience, and as tools for customizing their products. The Social Media can also be engaged as tools for tapping into customer creativity: utilizing advertising propositions generated by users that, according to evidence, are better accepted by their peers, or tapping customer ideas for innovation and promoting co-development.

The article has identified and explained the potential of Web 2.0 functionalities when applied to the retail sector. Both general (enhancing value of internet and physical retailing interactions) and specific benefits (reaching and retaining customers) can be achieved by combinations of different tools. The retailing environment becomes increasingly competitive and future survival and success will greatly depend on the degree to which retailers understand and welcome the empowered and highly sophisticated future consumer on board.

\section{Notes}

[1] The term Web 2.0 will be used in this paper alternatively as Social Media or Consumergenerated Media.

[2] According to McKinsey "television advertising in 2010 will be only $35 \%$ as effective as it was in 1990". 
[3] HitWise.com in a study published in April 2007 calculates the participation of Web 2.0 in the top participatory web sites at $12.28 \%$, an $68 \%$ increase compared to 2 years ago, http://www.hitwise.com/downloads/reports/Hitwise_US_Measuring_Web_2.0_Consum er_Participation_June_2007.pdf.

[4] Confer: https://www1.scene7.com/registration/2008_survey.asp?emaillist=Survey_2008 homepage.

[5] Social Networking Web sites and Teens, January 3, 2007.

[6] Confer: http://en.wikipedia.org/wiki/Social_networking.

[7] According to Technorati.com, a firm measuring the development of this phenomenon as of September 30, 2006, $1.3 \mathrm{~m}$ of blog posts are published daily, 54,000 per hour.

[8] Confer: http://business.timesonline.co.uk/tol/business/industry_sectors/media/article192 3706.ece.

[9] Confer: http://www.corporateresponsibilitygroup.com.

[10] Confer: http://www.bized.co.uk/current/index.htm.

[11] Voice over Internet Protocol i.e. connecting telephone subscribers by means of the Internet.

\section{References}

Awareness.com (2007): The World of Web 2.0, http://www.itbusinessinsider.com/op/ welcome_world_web_2.0/index.html, accessed January 17, 2008.

Anderson, P. (2007): What is Web 2.0? Ideas, Technologies and Implications for Education, in: JISC Technology and Standards Watch, February, pp. 1-64.

Beer, D.; Burrows, R. (2007): Sociology and, of and in Web 2.0: Some Initial Considerations, http://www.socresonline.org.uk/12/5/17.html, accessed December 13, 2007.

Bernhof, J.; Li, C. (2008): Harnessing the Power of the Oh-So-Social Web, in: MIT Sloan, Management Review, Vol. 49, No. 3, pp. 36-42.

Biever, C. (2006): Web 2.0 is all about the Feel-Good Factor, in: The New Scientist, Vol. 192, December 23, p. 30.

Birdsall, W.F. (2007): Web 2.0 as a Social Movement, http://www.webology.ir/2007/v4n2/ a40.html, accessed November 22, 2007.

Boll, S. (2007): MultiTube - Where Web 2.0 and Multimedia Could Meet, in: IEEE Multimedia, Vol. 14, No. 1, pp. 9-13.

Braceweel, V.; de Lussanet, M.; Camus, L. (2008): Trends 2008: European eCommerce and Online Retail, http://www.forrester.com/Research/Document/Excerpt/0,7211,44528,00. html, accessed January 24, 2008.

Bughin, J. (2008): The Rise of Enterprise 2.0, in: Journal of Direct, Data and Digital Marketing Practice, Vol. 9, No. 3, pp. 251-259.

Castañeda, L. (2007): Software Social Para la Escuela 2.0: más allá de los Blogs y las Wikis, in: Proceedings of X Congreso Internacional EDUTEC, Buenos Aires. 
Cerezo, J.M. (2007): La Web 2.0: ¿Revolución, Burbuja o Moda?, in: Harvard Deusto Marketing \& Ventas, Vol. 80, pp. 50-55.

Constantinides, E. (2002): The 4S Web-Marketing Mix Model. E-Commerce Research and Applications, in: Elsevier Science, Vol. 1, No. 1, pp. 57-76.

Constantinides, E. (2004): Influencing the Online Consumer's Behaviour: The Web Experience, in: Journal of Internet Research, Vol. 14, No. 2, pp. 111-126.

Constantinides, E.; Fountain, S. (2008): Web 2.0: Conceptual Foundations and Marketing Issues, in: Journal of Direct, Data and Digital Marketing Practice, Vol. 9, No. 3, pp. 231244.

Cordington, G. (2007): The Five Most Important People Trends in the Next Five Years, in: Civil Engineering, Vol. 15, No. 1, pp. 8-9.

Craig, E. (2007): Changing Paradigms: Managed Learning Environments and Web 2.0, in: Campus-wide Information Systems, Vol. 24, No. 3, pp. 151-161.

Cymfony (2006): Making the Case for a Social Media Strategy, http://www.cymfony.com/ files/pdf/making\%20the\%20case.pdf, accessed December 17, 2007.

Dans, E. (2007): La empresa y la Web 2.0, in: Harvard Deusto Marketing \& Ventas, Vol. 80, pp. 36-43.

DeFelice, A. (2006): A new Marketing Medium, http://www.destinationcrm.com/Articles/ Editorial/Magazine-Features/A-New-Marketing-Medium-47694.aspx, accessed December $16,2007$.

Deighton, J.; Kornfeld, L. (2007): Digital Interactivity: Unanticipated Consequences for Markets, Marketing, and Consumers, http://hbswk.hbs.edu/item/5783.html, accessed January $13,2008$.

Dellner, T. (2007): European E-commerce, http://www.electronicretailermag.com/info/0607 euro.html, accessed December 12, 2008.

Deshpande, A.; Jadad, A. (2006): Web 2.0: Could it Help Move the Health System into the $21^{\text {st }}$ Century?, in: The Journal of Men's Health \& Gender, Vol. 3, No. 4, pp. 332-336.

Drury, G. (2008): Opinion Piece: Social Media: Should Marketers Engage and how can it be done Effectively?, in: Journal of Direct, Data and Digital Marketing Practice, Vol. 9, No. 3, pp. 274-277.

Du, H.; Wagner, C. (2006): Weblog Success: Exploring the Role of Technology, in: International Journal Human - Computer studies, No. 64, pp. 789-798.

Facca, F.M.; Lanzi, P.L. (2004): Mining Interesting Knowledge from Weblogs: A Survey, in: Data and Knowledge Engineering, Vol. 53, No. 3, pp. 225-241.

Ganesh, J. (2007): Web 2.0 Adoption in Retail. Retail Web 2.0 Metrix (1,2,3,4 various posts), http://infosysblogs.com/web2/2007, accessed December 15, 2007.

Gilden, J. (2006): Travel Web Sites Gain Visitors by Offering more than Low Prices, in: Los Angeles Times, January 22, 2006.

Gillin, P. (2007): The New Influencers, a Marketer's Guide to the new Social Media, Sanger, CA.

Grewal, D.; Iyer, G.R.; Levy, M. (2004): Internet Retailing: Enablers, Limiters and Market Consequences, in: Journal of Business Research, Vol. 57, pp. 703-713. 
Hoegg, R.; Martignoni, R.; Meckel, M.; Stanoevska-Slabeva, K. (2006): Overview of Business Models for Web 2.0 Communities, in: Proceedings of GeNeMe 2006 Conference, Dresden.

Jain, A.; Ganesh, J. (2007a): Harnessing the Power of Web 2.0 in Online Retail. Part I: An overview of Web 2.0 adoption in Retail, http://www.infosys.com, accessed December 13, 2007.

Jain, A.; Ganesh, J. (2007b): Harnessing the Power of Web 2.0 in Online Retail. Part II: An Implementation Roadmap for Retailers, http://www.infosys.com, accessed December 13, 2007.

Karger, D.; Quan, D. (2004): What Would it Mean to Blog on the Semantic Web?, in: Lecture Notes in Computer Science, Vol. 3298, pp. 214-228.

Korica, P.; Mauer, H.; Schinagl, W. (2006): The Growing Importance of E-Communities on the Web, in: Proceedings IADIS International Conference, San Sebastian.

Li, C.; Bernoff, J.; Feffer, K.A.; Pflaum, C.N. (2007): Marketing on Social Networking Sites, http://www.forrester.com/Research/Document/Excerpt/0,7211,41662,00.html, accessed November 14, 2007.

McAfee, A. (2006): Enterprise 2.0: The Dawn of Emergent Collaboration, in: MIT Sloan Management Review, Vol. 47, No. 3, pp. 21-28.

McKenna, R. (1997): Real time: Preparing for the Age of the Never Satisfied Customer, Boston, MA.

McKinsey (2007a): Eight Technology Trends to Watch, http://www.mckinseyquarterly.com/ Information_Technology/Applications/Eight_business_technology_trends_to_watch_2080 _abstract, accessed January 26, 2008.

McKinsey (2007b): How Companies are marketing online, http://www.mckinsey quarterly.com/How_companies_are_marketing_online_A_McKinsey_Global_Survey_ 2048 abstract, accessed January 26, 2008.

McKinsey (2007c): How Businesses are Using Web 2.0, http://www.mckinsey quarterly.com/How_businesses_are_using_Web_20_A_McKinsey_Global_Survey_1913_ abstract, accessed December $15,2007$.

Moral, J.A. del (2007): Marketing Viral o Marketing 2.0, in: Harvard Deusto Marketing \& Ventas, Vol. 80, pp. 44-49.

Newsweek (2007): The New Wisdom of the Web, http://www.newsweek.com/id/45976/ page/2, accessed January 16, 2008.

Nielsen, J. (2007): Web 2.0 can be Dangerous..., http://www.useit.com/alertbox/web-2.html, accessed December 17, 2007.

O'Reilly, T. (2005): What is Web 2.0. Design Patterns and Business Models for the Next Generation of Software, http://www.oreillynet.com/pub/a/oreilly/tim/news/2005/09/30/ what-is-web-20.html, accessed November 17, 2008.

Parise, S.; Guinan, P.J. (2008): Marketing Using Web 2.0, in: Proceedings of the $41^{\text {st }}$ Hawaii International Conference on System Sciences, Manoa, HI.

Prospero.com (2007): Prospero Press Release, http://www.prospero.com/about_press release_071016.asp, accessed October 16, 2007. 
SpannerWorks (2007): What is Social Media?, http:/www.icrossing.co.uk/fileadmin/uploads/ eBooks/What_is_social_media_Nov_2007.pdf, accessed January 14, 2008.

Stroud, D. (2008): Social Networking: An Age-Neutral Commodity-Social Networking Become a Mature Web Application, in: Journal of Direct, Data and Digital Marketing Practice, Vol. 9, No. 3, pp. 278-292.

Swisher, P.S. (2007): The Managed Web: A Look at the Impact of Web 2.0 on Media Asset Management for the Enterprise, in: Journal of Digital Asset Management, Vol. 3, pp. 3242.

Tancer, B. (2007): Hitwise US Research Note - Measuring Web 2.0 Consumer Participation, http://www.hitwise.com/downloads/reports/Hitwise_US_Measuring_Web_2.0_Consumer_ Participation_June_2007.pdf, accessed November 27, 2007.

Urban, G. (2003): Customer Advocacy: Is it for you?, Center for eBusiness@MIT Paper 175, Cambridge, MA.

Urban, G. (2005): Don't Just Relate - Advocate! A Blueprint for Profit in the Era of Customer Power, Upper Saddle River, NJ.

Yakel, E. (2006): Inviting the User into the Virtual Archives, in: OCLC Systems and Services, Vol. 22, No. 3, pp. 159-163.

Van der Veen, M. (2004): Explaining E-Business Adoption, in: Innovation and Entrepreneurship in Dutch SMEs, Twente.

Wang, L.C.; Baker, J.; Wagner, J.A.; Wakefield, K. (2007): Can a Retail Web Site be Social?, in: Journal of Marketing, Vol. 71, No. 3, pp. 143-157.

Zogby International (2008): Zogby Poll: 67\% View Traditional Journalism as "Out of Touch", http://www.zogby.com/news/ReadNews.dbm?ID=1454, accessed February 27, 2008. 